\title{
X-ray Structure and Magnetic Properties of two new iron(II) 1D Coordination Polymers with Bis(imidazolyle)methane as bridging ligand
}

\begin{tabular}{|r|l|}
\hline Journal: & Zeitschrift für Anorganische und Allgemeine Chemie \\
\hline Manuscript ID: & zaac. 200900291.R1 \\
\hline Wiley - Manuscript type: & Article \\
\hline Date Submitted by the & 04-Aug-2009 \\
Author: & \\
\hline Complete List of Authors: & Weber, Birgit; LMU München, Chemie und Biochemie \\
\hline Keywords: & Iron Complexes, Magnetism, X-Ray structure \\
\hline &
\end{tabular}

\section{s ScholarONE" \\ Manuscript Central}




\title{
ARTICLE
}

DOI: 10.1002/zaac.200((will be filled in by the editorial staff))

\section{X-ray Structure and Magnetic Properties of two new iron(II) 1D Coordination Polymers with Bis(imidazolyle)methane as bridging ligand}

\author{
Toni Pfaffeneder, Wolfgang Bauer, Birgit Weber*
}

Keywords: Iron; Magnetic properties, Schiff bases; Spin Crossover

The reaction of iron(II) acetate with the tetradentate Schiff base like ligands $\quad \mathrm{H}_{2} \mathrm{~L} 1 \quad((\mathrm{E}, \mathrm{E})-[\{$ diethyl 2,2'-[1,2-phenylenebis(iminomethyl-idyne) ]bis[3-oxobutanato $\}])$ and $\mathrm{H}_{2} \mathrm{~L} 2$ ([([3,3']-[1,2phenylene-bis(iminomethylidyne)]bis(2,4-pentane-dionato)(2-)$\left.\mathrm{N}, \mathrm{N}^{\prime}, \mathrm{O} 2, \mathrm{O}^{\prime}\right]$ ) leads to the formation of the octahedral $\mathrm{N}_{2} \mathrm{O}_{4}$ coordinated iron complexes $\left[\mathrm{FeL} 1(\mathrm{MeOH})_{2}\right]$ and $\left[\mathrm{FeL} 2(\mathrm{MeOH})_{2}\right]$, respectively. Conversion of both with bimm (bis(1imidazolyle)methane) leads to the $1 \mathrm{D}$ coordination polymers $[\mathrm{FeL} 1(\mathrm{bimm})] \cdot 0.5(\mathrm{MeOH})(\mathbf{1})$ and $[\mathrm{FeL} 2(\mathrm{bimm})](\mathbf{2})$.

[*] Center for Integrated Protein Science Munich at the Department Chemie und Biochemie Ludwig-Maximilians-Universität München Butenandtstr. 5-13 (Haus F), D-81377 München, Germany

Fax: (+49)89-2180-77407

E-mail: bwmch@cup.uni-muenchen.de

\section{Introduction}

Spin transition complexes (spin crossover, SCO) are an interesting class of compounds that can be switched between two or more states by physical perturbations such as temperature, pressure or light [1]. Several applications in the field of information technology can be envisioned for this class of substance, especially for complexes that exhibit a wide hysteresis around room temperature (memory effect) [2]. The occurrence of hysteresis and other types of SCO such as stepwise or abrupt spin transitions depends on the cooperative effects between the metal centers during the spintransition. Different intermolecular interactions such as $\pi$-stacking, hydrogen bonds or van der Waals interactions are suitable transmitters for these effects. The application of covalent linkers as suggested by Kahn et al. [2a] did attract special attention over the last years as the spreading of those interactions can be more easily controlled. This resulted in the synthesis and characterization of several iron(II) spin crossover coordination polymers [3]. We have shown in a recent review [4], that covalent linkers, most likely, have not the ability to transmit the geometric changes associated with the spin transition through the crystal lattice and, by this, increase the cooperative interactions. We have clearly demonstrated that the increase of cooperative effects during the spin transition is mainly due to an increased number of intermolecular contacts. Furthermore our results have shown that covalent linkers can be used to optimize the packing of the molecules in the crystal in a crystal engineering like approach [4]. Next to spin transitions with wide thermal hysteresis loops step wise transitions are also of
Compound $\mathbf{1}$ is a pure high-spin (HS) complex, which was characterised using magnetic measurements and X-ray structure analysis. Compound $\mathbf{2}$ undergoes an irregular and incomplete thermal spin transition. interest because of the possibility of addressing more than two different states. The factor, which determines the presence or absence of steps in the transition curve of coordination polymers is the packing of the molecules in the crystals. For the previously reported complex $[\mathrm{FeL} 2(\mathrm{bppa})] \cdot(\mathrm{MeOH}) \quad(\mathrm{bppa}=1,3-\mathrm{bis}(4-$ pyridyle)propane) [4] a stepwise spin crossover was observed, due to a zigzag-like structure of the 1D chain with alternating HS and LS iron(II) centers on the step. Due to the zigzag-structure the inter-chain $\mathrm{Fe} \cdots \mathrm{Fe}$ distances cannot follow the $\mathrm{Fe}-\mathrm{L}$ distance changes upon spin transition as easily as compared to linear structures because of restraining interactions (steric hinderances) between the neighboring chains. Very likely this is the reason for the stabilization of the wide step. Similar structures and magnetic properties could be obtained by the usage of the axial ligand bis(1imidazolyle)methane (bimm) instead of bppa. So far only few coordination polymers were reported for this ligand that were obtained through the self-assembly with different metal centres [5]. Those structures indicate that the bimm ligand is well suited for the generation of zigzag chain structures. In this paper we present the synthesis and characterisation of two polymer iron(II) complexes $[\mathrm{FeL1}$ (bimm)]·0.5(MeOH) and [FeL2(bimm)].

\section{Results and Discussion}

\section{Synthesis of the complexes}

The general route for the synthesis of the 1D octahedral iron(II) coordination polymers is depicted in Scheme 1. The complexes could be obtained in a two-pot reaction. In a first step an iron complex of the tetradentate equatorial ligand $\left(\mathrm{H}_{2} \mathrm{~L} 1 / 2\right)$ with methanol as axial ligands was prepared [6]. In a second step $\left[\mathrm{FeL} 1 / 2(\mathrm{MeOH})_{2}\right]$ was converted with the axial ligand bimm. To give [FeL1(bimm)]·0.5(MeOH) (1) and [FeL2(bimm)] (2), a 5 fold molar excess of the axial ligand was used. Both complexes were 
characterised by elemental analysis, IR and mass spectroscopy as well as $T$-dependent magnetic susceptibility measurements.
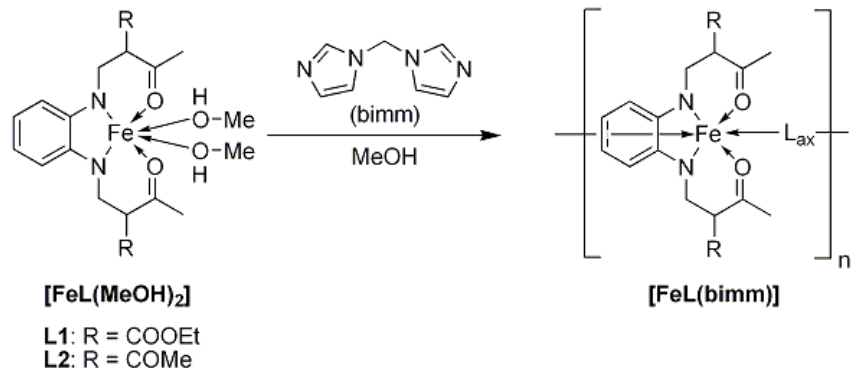

Scheme 1. General procedure for the synthesis of the 1D octahedral iron(II) coordination polymers.

\section{$X$-ray structure analysis}

Crystals suitable for X-ray structure analysis were obtained only for 1 . The crystallographic data are summarized in Table 1. Figure 1 displays the asymmetric unit of the octahedral complex. Selected bond lengths and angles within the first coordination sphere are summarized in Table 2.

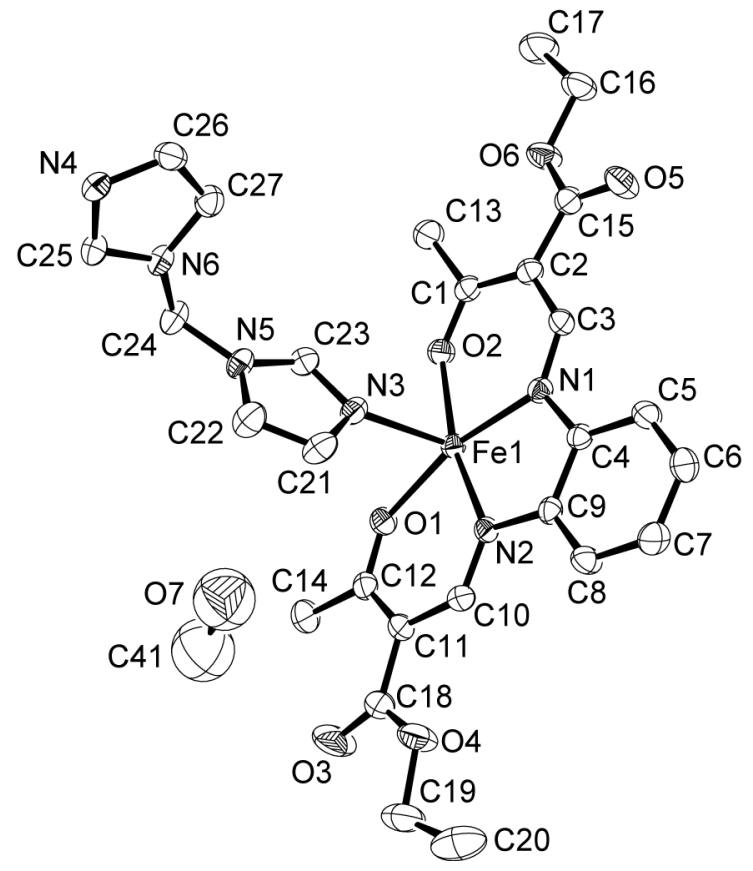

Figure 1. ORTEP drawing of the asymmetric unit of $\mathbf{1}$. Hydrogen atoms were omitted for clarity. Thermal ellipsoids are shown at the $50 \%$ probability level.

The bond lengths and angles within the first coordination sphere of $\mathbf{1}$ are within the region reported for HS iron(II) complexes of the same ligand type [7]. The average bond lengths are $2.09 \AA\left(\mathrm{Fe}-\mathrm{N}_{\mathrm{eq}}\right)$ $2.03 \AA\left(\mathrm{Fe}-\mathrm{O}_{\mathrm{eq}}\right)$ and $2.25 \AA\left(\mathrm{Fe}-\mathrm{N}_{\mathrm{ax}}\right)$. A characteristic tool for the determination of the spin state of this type of iron(II) complexes is the $\mathrm{O}-\mathrm{Fe}-\mathrm{O}$ angle that changes from about $110^{\circ}$ in the HS state to about $90^{\circ}$ in the LS state [7]. For the complex reported here, the angle is with $109^{\circ}$ clearly in the region typical for the HS state. The $\mathrm{N}_{\mathrm{ax}}-\mathrm{Fe}-\mathrm{N}_{\mathrm{ax}}$ angle differs, with $168^{\circ}$, significantly from the expected $180^{\circ}$ for an ideal octahedron. A possible explanation for the strong distortion is the intermolecular network of non-classical $\mathrm{H}$-bonds between the axial and the equatorial ligand (C27$\mathrm{H} 27 \cdots \mathrm{O} 5, \mathrm{C} 24-\mathrm{H} 24 \cdots \mathrm{O} 1)$. Selected intermolecular distances shorter than the sum of the van der Waals radii are summarized in Table 3. In Figure 2 the packing of the complex in the crystal is displayed. For a better understanding of the magnetic properties it is in general necessary to investigate short contacts in the crystal packing. Besides the two contacts, which have been already mentioned, there is a further non-classical H-bond (C6-H6…O3), which contributes to a $3 \mathrm{D}$ network of intermolecular interactions

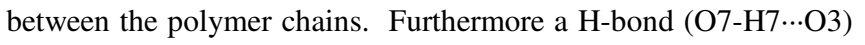
between the hydroxyl group of the additional solvent molecule methanol in the crystal and a carbonyl group of the equatorial ligand is formed (Table 3). The methanol molecules occupy a special position (inversion center) and therefore a disorder model was applied. The equatorial ligands within a 1D chain are ordered in a parallel manner, because of the distortion of the imidazolyle rings of the axial ligand.

Table 1. Crystallographic data of $\mathbf{1}$ discussed in this work.

\begin{tabular}{ll}
\hline Complex & $\mathbf{1}$ \\
\hline empirical formula & $\mathrm{C}_{27.5} \mathrm{H}_{32} \mathrm{FeN}_{6} \mathrm{O}_{6.5}$ \\
formula weight & 606.42 \\
temperature $/ \mathrm{K}$ & 200 \\
crystal size $/ \mathrm{mm}$ & $0.38 \times 0.34 \times 0.32$ \\
crystal system & triclinic \\
space group & $P \overline{1}$ \\
$\lambda / \AA$ & 0.71069 \\
$a / \AA$ & $10.7629(3)$ \\
$b / \AA$ & $11.6648(3)$ \\
$c / \AA$ & $12.3748(3)$ \\
$\alpha /{ }^{\circ}$ & $112.978(3)$ \\
$\beta /{ }^{\circ}$ & $94.543(2)$ \\
$\gamma /{ }^{\circ}$ & $91.001(2)$ \\
$V / \AA^{3}$ & $1423.87(6)$ \\
$Z$ & 1 \\
$\rho_{\text {calc }} / \mathrm{g} / \mathrm{cm}^{3}$ & 1.414 \\
$\mu / \mathrm{mm}{ }^{-1}$ & 0.584 \\
$F(000)$ & 634 \\
$\Theta$ range $/^{\circ}$ & $3.8-26.1$ \\
reflections collected & 26315 \\
reflections unique & $5632\left(\mathrm{R}_{\text {int }}=0.0343\right)$ \\
$R 1($ all $)$ & $0.0338(0.0477)$ \\
$w R 2$ & 0.0910 \\
$G o o F$ & 1.065 \\
\hline
\end{tabular}

Table 2. Selected bond lengths $[\AA]$ and angles [degree] within the first coordination sphere of $\mathbf{1}$ at $200 \mathrm{~K}$.

\begin{tabular}{lllll}
\hline Fe- $\mathrm{N}_{\mathrm{eq}}$ & $\mathrm{Fe}-\mathrm{O}_{\mathrm{eq}}$ & $\mathrm{Fe}-\mathrm{L}_{\mathrm{ax}}$ & $\mathrm{O} 1-\mathrm{Fe}-\mathrm{O} 2$ & $\mathrm{~L}_{\mathrm{ax}}-\mathrm{Fe}-\mathrm{L}_{\mathrm{ax}}$ \\
\hline $2.098(2)$, & $2.048(1)$, & $2.230(1)$, & $108.59(5)$ & $167.52(6)$ \\
$2.083(1)$ & $2.019(1)$ & $2.262(1)$ & & \\
\hline
\end{tabular}

Table 3. Selected intermolecular distances $[\AA]$ and angles [degree] of 1 at $200 \mathrm{~K}$.

\begin{tabular}{lllll}
\hline & $\mathrm{D}-\mathrm{H}$ & $\mathrm{H} \cdots \mathrm{A}$ & $\mathrm{A} \cdots \mathrm{D}$ & $\mathrm{D}-\mathrm{H} \cdots \mathrm{A}$ \\
\hline $\mathrm{O} 7-\mathrm{H} 7 \cdots \mathrm{O} 3^{[\mathrm{a}]}$ & 0.84 & 2.32 & $2.956(6)$ & 133 \\
$\mathrm{C}^{\mathrm{b}}-\mathrm{H} 6 \cdots 3^{[\mathrm{b}]}$ & 0.95 & 2.38 & $3.185(3)$ & 143 \\
$\mathrm{C} 24-\mathrm{H} 24 \cdots \mathrm{O} 1^{[\mathrm{c}]}$ & 0.95 & 2.27 & $3.258(2)$ & 174 \\
$\mathrm{C} 27-\mathrm{H} 27 \cdots \mathrm{O} 5^{[\mathrm{d}]}$ & 0.95 & 2.36 & $3.302(3)$ & 173 \\
\hline
\end{tabular}

[a] 1-x,-y,1-z; [b] x,1+y,z; [c] 1-x,-y,-z; [d] 1-x,1-y,-z. 

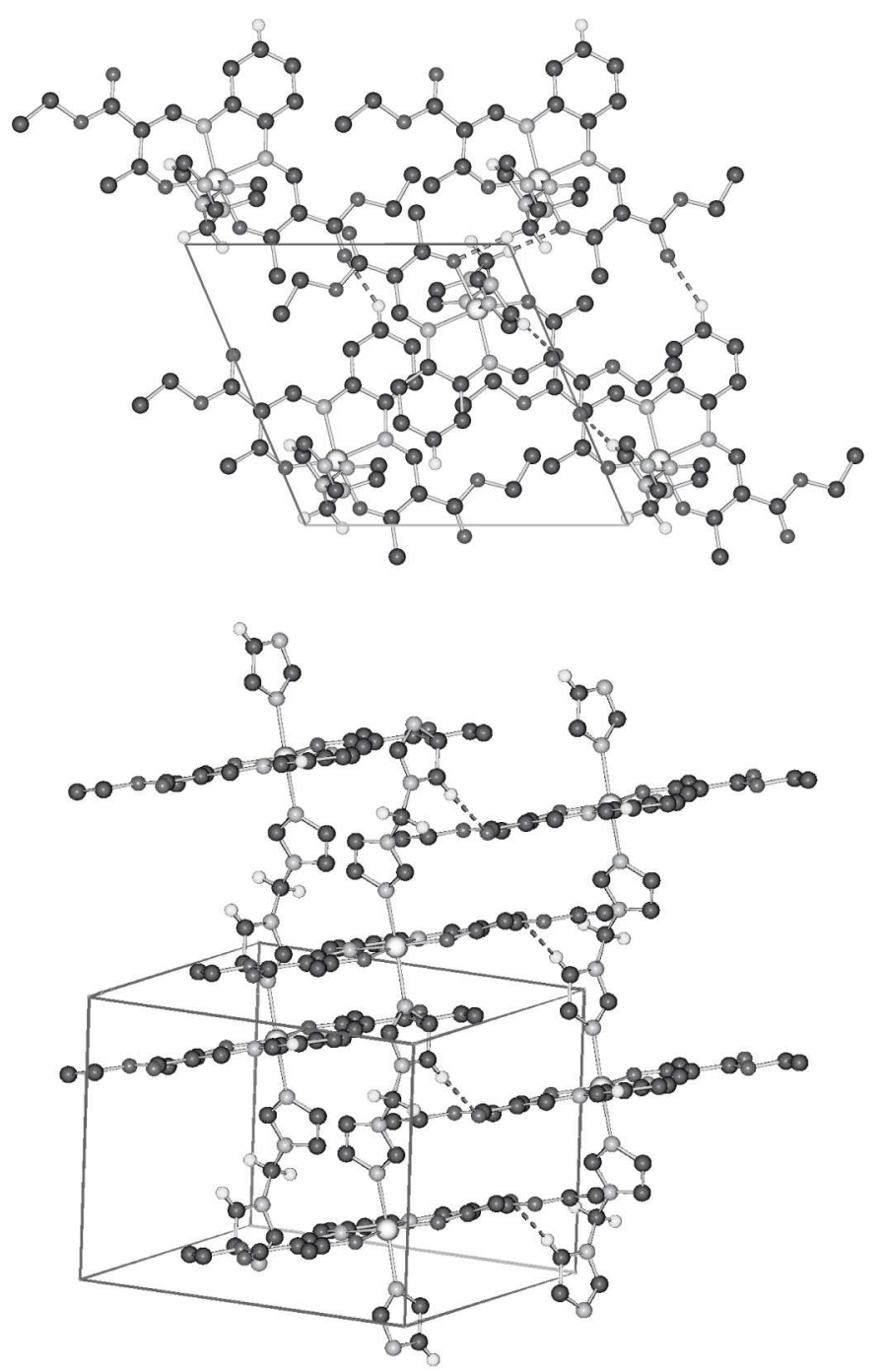

Figure 2. Top: Packing of compound $\mathbf{1}$ in the crystal at $200 \mathrm{~K}$; view along [100], bottom: excerpt of a 2D layer of parallel polymer chains. Solvent molecules and $\mathrm{H}$-atoms, which do not participate in H-bonding, have been omitted for clarity.

\section{Magnetic susceptibility data}

Magnetic susceptibility measurements for both compounds were investigated in the temperature range from 295 to $10 \mathrm{~K}$ at $0.05 \mathrm{~T}$ using a Quantum Design MPMSR-XL SQUID magnetometer. Figure 3 displays the thermal dependence of the $\chi_{\mathrm{M}} T$ product for both compounds. For compound 1 (top of Fig. 3) nearly ideal curie behaviour is observed. Upon cooling, the $\chi_{\mathrm{M}} T$ product decreases from a value of $3.34 \mathrm{~cm}^{3} \mathrm{Kmol}^{-1}$ at $295 \mathrm{~K}$ to a value of $3.08 \mathrm{~cm}^{3} \mathrm{Kmol}^{-1}$ at $20 \mathrm{~K}$. The susceptibility data above $20 \mathrm{~K}$ can be fitted very well with the Curie-Weiss law $\left(\chi_{\mathrm{M}}=C /(T-\Theta)\right)$ with the parameters $\Theta=-2.71 \mathrm{~K}$ and $C=3.34 \mathrm{~cm}^{3} \mathrm{Kmol}^{-1}$. The Curie constant $C$ is in a region expected for iron(II) HS complexes and the negative Weiss constant $\Theta$ in combination with the temperature-dependent decrease of the $\chi_{\mathrm{M}} T$ product is an indication for weak antiferromagnetic interactions between the spin centres. Compound $\mathbf{1}$ is a typical iron(II) HS complex. For compound 2 (bottom of Fig. 3) the situation is more complex. Upon cooling, the $\chi_{\mathrm{M}} T$ product decreases from a value of $3.31 \mathrm{~cm}^{3} \mathrm{Kmol}^{-1}$ at $295 \mathrm{~K}$ to a value of $1.37 \mathrm{~cm}^{3} \mathrm{Kmol}^{-1}$ at $50 \mathrm{~K}$. The room temperature value is in the region typical for an iron(II) HS complex. The curve progressing is very irregular with three steps, a remaining HS molar fraction and a small hysteresis for the last step. Crystals suitable for X-ray analysis were not obtained until now to elucidate the structural reasons for this behavior. Likely the structure is similiar to the observed structure of compound $\mathbf{1}$, because the equatorial ligands vary only in a small residue (methyl instead of ethanoyl group), which do not participate in intermolecular interactions. A similar network of short contacts like the observed 3D network of non-classical H-bonds in $\mathbf{1}$ could be the reason for the cooperative effects (hysteresis) during the spin transition of compound 2. However, the multitude of different steps indicates that there are probably more than two different iron centres. One reason could be that two or more modifications of the polymer chain with different orientations of the rather flexible bimm ligand co-precipitate at the same time. The different plateaus in the transition curve of $\mathbf{2}$ are less pronounced compared to the complex [FeL2(bppa)].(MeOH) [4] in agreement with the almost linear chain structure observed for $\mathbf{1}$.
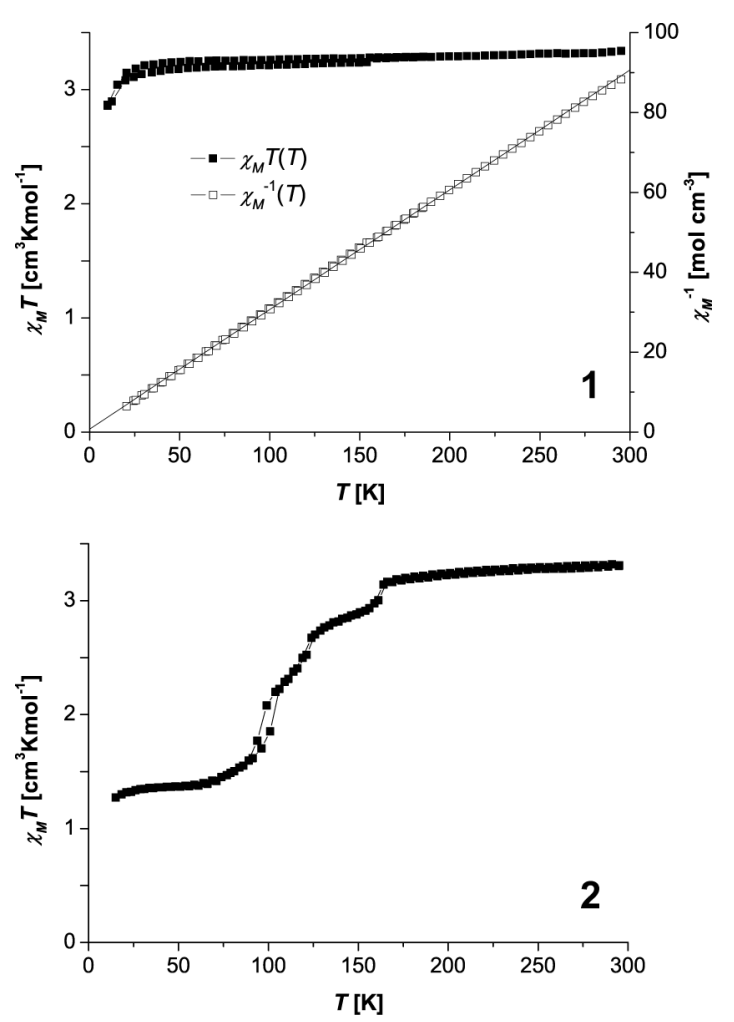

Figure 3. Plots of $\chi_{\mathrm{M}} T$ product (filled squares) vs. $T$ for the compunds 1 and 2. Reciprocal molar susceptibility $\chi_{\mathrm{M}}{ }^{-1}$ (open squares) as function of temperature $T$ and the fits according to the Curie Weiss law, $\chi_{\mathrm{M}}=C /(T-\Theta)$, with the parameters $\Theta=-2.71 \mathrm{~K}$, $\mathrm{C}=3.34 \mathrm{~cm}^{3} \mathrm{Kmol}^{-1}$ for compound $\mathbf{1}$.

\section{Conclusions}

We have expected similiar structures and magnetic properties for the newly synthesized iron(II) coordination polymers with the axial ligand bimm as we have observed for the analogous complex [FeL2(bppa)].(MeOH) [4]. The latter undergoes a stepwise thermal spin transition with a wide plateau due to a zigzag-like structure, which stabilizes the step according to restraining interchain interactions. In the case of the HS compound $\mathbf{1}$ the formation of a 
zigzag-like chain is prevented by a distortion of the imidazolyle rings of bimm. For compound $\mathbf{2}$ an irregular and incomplete spin transition was observed, which indicates several steps and a small hysteresis. Since we have not obtained suitable crystals, we could not elucidate the reason for the magnetic behaviour of this complex. Due to the high flexibility of the bimm ligand the co-precipitation of two or more modifications of the complex with different orientations of the bimm ligand cannot be excluded. For a better understanding and predictability of SCO properties less flexible bridging ligands are necessary.

\section{Experimental Section}

\section{Synthesis}

All synthesis were carried out under argon using Schlenk tube tequniques. Methanol was purified as described in literature [8] and distilled under argon. The synthesis of the ligands $\mathrm{H}_{2} \mathrm{~L} 1$ and $\mathrm{H}_{2} \mathrm{~L} 2$ [9] and $\left[\mathrm{FeL} 1 / 2(\mathrm{MeOH})_{2}\right][10]$ is already described in literature.

Bis(1-imidazolyle)methane (bimm): The ligand bimm, whose synthesis has already been reported [11], has been prepared according to the procedure for the synthesis of bis(1-pyrazolyle)methane described in ref 12 and recrystallized from chloroform. $\mathrm{C}_{7} \mathrm{H}_{8} \mathrm{~N}_{4}$ (148.07); C 56.26 (calc 56.74); H 5.30 (5.44); N 37.48 (37.81)\%. ${ }^{1} \mathrm{H}-\mathrm{NMR}\left(400 \mathrm{MHz},\left[\mathrm{D}_{6}\right] \mathrm{DMSO}, 22{ }^{\circ} \mathrm{C}\right): \delta=7.9$ (s, 2 H), 7.4 (ps, $2 \mathrm{H}), 6.9$ (ps, $2 \mathrm{H}), 6.2$ (s, $2 \mathrm{H} ; \mathrm{CH}_{2}$ ). MS (DEI $\left.{ }^{+}\right): \mathrm{m} / \mathrm{z}=$ $148\left(\mathrm{M}^{+}, 53 \%\right), 81\left(\mathrm{M}^{+}-\mathrm{C}_{3} \mathrm{H}_{3} \mathrm{~N}_{2}, 100 \%\right)$.

[FeL1(bimm)] 0.5(MeOH) (1): A suspension of $0.99 \mathrm{mmol}$ $(0.50 \mathrm{~g})\left[\mathrm{FeL} 1(\mathrm{MeOH})_{2}\right]$ and $4.99 \mathrm{mmol}(0.74 \mathrm{~g})$ bimm were refluxed in $20 \mathrm{~mL}$ methanol for $1 \mathrm{~h}$. After cooling the dark brown precipitate was filtered off, washed with methanol $(5 \mathrm{~mL})$ and dried in vacuum. Yield: $0.50 \mathrm{~g}(83 \%) . \mathrm{C}_{27.5} \mathrm{H}_{32} \mathrm{FeN}_{6} \mathrm{O}_{6.5}$ (606.42): C 54.39 (calc 54.47); H 5.04 (5.32); N 14.04 (13.86)\%. IR (KBr): $v$ $=1688 \mathrm{~m}(\mathrm{COO}), 1663 \mathrm{~m}, 1571 \mathrm{~s}(\mathrm{CO}) \mathrm{cm}^{-1}$. MS $\left(\mathrm{DEI}^{+}\right): \mathrm{m} / \mathrm{z}=$ $443\left([\mathrm{FeL} 1]^{+}+\mathrm{H}, 26 \%\right), 442\left([\mathrm{FeL} 1]^{+}, 100 \%\right), 397\left([\mathrm{FeL} 1]^{+}\right.$ $\left.-\mathrm{OC}_{2} \mathrm{H}_{5}, 22 \%\right), 396\left([\mathrm{FeL} 1]^{+}-\mathrm{OC}_{2} \mathrm{H}_{5}-\mathrm{H}, 12 \%\right), 354\left([\mathrm{FeL} 1]^{+}\right.$ $\left.-\mathrm{OC}_{2} \mathrm{H}_{5}-\mathrm{COCH}_{3}, 25 \%\right), 323(10)\left([\mathrm{FeL} 1]^{+}-\mathrm{OC}_{2} \mathrm{H}_{5}-\mathrm{COCH}_{3}\right.$ $\left.-\mathrm{C}_{2} \mathrm{H}_{5}, 10 \%\right), 309\left([\mathrm{FeL} 1]^{+}-2\left(\mathrm{OC}_{2} \mathrm{H}_{5}\right)-\mathrm{COCH}_{3}, 23 \%\right), 148$ (bimm $\left.{ }^{+}, 43 \%\right), 81\left(\right.$ bimm $\left.^{+}-\mathrm{C}_{3} \mathrm{H}_{3} \mathrm{~N}_{2}, 60 \%\right), 43\left(\mathrm{COCH}_{3}{ }^{+}, 21 \%\right)$. Single crystals of 1 were slowly formed by diffusion techniques in methanol solution after several weeks.

[FeL2(bimm)] (2): A suspension of $0.54 \mathrm{mmol} \quad(0.24 \mathrm{~g})$ $\left[\mathrm{FeL} 2(\mathrm{MeOH})_{2}\right]$ and $2.69 \mathrm{mmol}(0.40 \mathrm{~g})$ bimm were refluxed in $15 \mathrm{~mL}$ methanol for $1 \mathrm{~h}$. After cooling the dark brown precipitate was filtered off, washed with methanol $(5 \mathrm{~mL})$ and dried in vacuum. Yield $0.24 \mathrm{~g}(84 \%) . \mathrm{C}_{25} \mathrm{H}_{26} \mathrm{FeN}_{6} \mathrm{O}_{4}$ (530.36): C 56.05 (calc 56.62); H 4.95 (4.94); N 15.55 (15.85)\%. IR (KBr): $v=1558$ vs $(\mathrm{CO}) \mathrm{cm}^{-1}$. MS $\left(\mathrm{DEI}^{+}\right): \mathrm{m} / \mathrm{z}=383\left([\mathrm{FeL} 2]^{+}+\mathrm{H}, 22 \%\right), 382$ $\left([\mathrm{FeL} 2]^{+}, 96 \%\right), 367\left([\mathrm{FeL} 2]^{+}-\mathrm{CH}_{3}, 27 \%\right), 148$ (bimm $\left.^{+}, 72 \%\right), 81$ $\left(\mathrm{bimm}^{+}-\mathrm{C}_{3} \mathrm{H}_{3} \mathrm{~N}_{2}, 100 \%\right), 43\left(\mathrm{COCH}_{3}^{+}, 71 \%\right)$.

\section{Magnetic measurements}

Magnetic measurements of the fine crystalline samples were performed on a Quantum-Design-MPMSR2-SQUID-Magnetometer in a temperature range from 10 to $295 \mathrm{~K}$. The measurements were carried out at $0.05 \mathrm{~T}$ in the settle mode. The data were corrected for the magnetisation of the sample holder and diamagnetic corrections were made using tabulated Pascals constants.

\section{X-ray Crystallography}

The intensity data of $\mathbf{1}$ were collected on a Oxford XCalibur diffractometer using graphite-monochromated Mo-K $\alpha$ radiation. Data were corrected for Lorentz and polarisation effects. The structure was solved by direct methods (Sir 97 [13]) and refined by full-matrix least-square techniques against F02 (SHELXL-97 [14]). The hydrogen atoms were included at calculated positions with fixed thermal parameters. ORTEP-III was used for structure representation [15]. Crystallographic data are summarized in Table 1. Selected distances and angles are presented in Table 2. Further details on the crystal structures (CCDC-734192 for 1) can be obtained free of charge on application to Cambridge Crystallographic Data Centre, 12 Union Road, Cambridge CB2 1EZ, UK (Fax: int.code+(1223)336-033; e-mail fileserv@ccdc.cam.ac.uk).

\section{Acknowledgments}

This work has been supported financially by the Deutsche Forschungsgemeinschaft (SPP 1137) the Fonds der Chemischen Industrie, the Center for Integrated Protein Science Munich (CIPSM) and the University of Munich.

[1] a) H. A. Goodwin, Coord. Chem. Rev. 1976, 18, 293; b) P. Gütlich, Struct. Bonding (Berlin) 1981, 44, 83; c) E. König, Prog. Inorg. Chem. 1987, 35, 527; d) P. Gütlich, A. Hauser, Coord. Chem. Rev. 1990, 97, 1; e) E. König, Struct. Bonding (Berlin) 1991, 76, 51; f) P. Gütlich, A. Hauser, H. Spiering, Angew. Chem. Int. Ed. Engl. 1994, 33, 2024, and references therein; g) P. Gütlich, J. Jung, H. Goodwin, Molecular Magnetism : From Molecular Assemblies to the Devices, Eds. Coronado et al., NATO ASI Series E: Applied Sciences, 1996, 321, 327; h) P. Gütlich, H. A. Goodwin, (editors); "Spin Crossover in Transition Metal Compounds I-III", Topics in Current Chemistry, Springer-Verlag Berlin Heidelberg New York 2004; i) J. A. Real, A. B. Gaspar, M. C. Munoz, Dalton Trans. 2005, 2062, j) O. Sato, J. Tao, Y.-Z. Zhang, Angew. Chem. 2007, 119, 2200; Angew. Chem. Int. Ed. 2007, 46, 2152-2187.

[2] a) O. Kahn, C. Jay Martinez, Science 1998, 279, 44-48; (b) O. Kahn, C. Jay, J. Kröber, R. Claude, F. Grolière, Patent 1995 EP0666561; (c) J.-F. Létard, O. Nguyen, N. Daro, Patent 2005 FR0512476; (d) J.-F. Létard, P. Guionneau, L. Goux-Capes, Topics in Current Chemistry, Eds. P. Gütlich et H.A. Goodwin, Springer WienNewYork, 2004, 235, 221; (e) A. Galet, A. B. Gaspar, M. C. Munoz, G. V. Bukin, G. Levchenko, J. A. Real, Adv. Mater. 2005, 17, 2949-2953.

[3] a) C. Genre, G. S. Matouzenko, E. Jeanneau, D. Luneau, New J. Chem. 2008, 30, 1669; b) P. J. van Koningsbruggen, Y. Garcia, O. Kahn, L. Fournés, H. Kooijman, A. L. Spek, J. G. Haasnoot, J. Moscovici, K. Provost, A. Michalowicz, F. Renz, P. Gütlich, Inorg. Chem. 2000, 39, 1891; c) N. Moliner, M. C. Munoz, S. Létard, L. Salmon, J.-P. Tuchagues, A. Bousseksou, J. A. Real, Inorg. Chem. 2002, 41, 6997; d) J. A. Real, E. Andrés, M. C. Munoz, M. Julve, T. Granier, A. Bousseksou, F. Varret, Science 1995, 268, 265; e) N. Moliner, M. C. Munoz, S. Létard, X. Solans, N. Menéndez, A. Goujon, F. Varret, J. A. Real, Inorg. Chem. 2000, 39, 5390; f) G. S. Matouzenko, G. Molnár, N. Bréfuel, M. Perrin, A. Bousseksou, S. A. Borshch, Chem. Mater. 2003, 15, 550. g) Y. Garcia, V. Niel, M. C. Munoz, J. A. Real, Top. Curr. Chem. 2004, 233, 229; h) G. S. Matouzenko, M. Perrin, B. Le Guennic, C. Genre, G. Molnár, A. Bousseksou, S. A. Borshch, Dalton Trans. 2007, 934-942; i) J. A. Real, A. B. Gaspar, V. Niel, M. C. Munoz, Coord. Chem. Rev. 2003, 236, 121-141; j) S. M. Neville, B. A. Leita, D. A. Offermann, M. B. Duriska, B. Moubaraki, K. W. Chapman, G. J. Halder, K. S. Murray, Eur. J. Inorg. Chem. 2007, 1073-1085; k) K. S. Murray, C. J. Kepert, Top. Curr. Chem. 2004, 233, 195-228. 
[4] B. Weber, Coord. Chem. Rev. 2008, doi:10.1016/ j.ccr.2008.10.002.

[5] a) G. H. Cui, J. R. Li, J. L. Tian, X. H. Bu, S. R. Batten, Cryst. Growth Des. 2005, 5, 1775-1780; b) S.W. Jin, W.Z. Chen, Polyhedron 2007, 26, 3074-3084; c) N. Masciocchi, C. Pettinari, E. Alberti, R. Pettinari, C. D. Nicola, A. F. Albisetti, A. Sironi, Inorg. Chem. 2007, 46, 10501-10509; d) C. M. Jin, Z. F. Chen, T. Q. Sun, Y. J. Hu, S. L. Hu, J. Mol. Struct. 2008, 889, 186-190. e) C.-M. Jin, Z.-F. Chen, H.-F. Mei, X.K. Shi, J. Mol. Struct. 2009, 921, 58-62.

[6] B. Weber, A contribution to a deeper understanding of the nature of the ironnitrosyl bond in bioanalogue iron complexes, Dissertation, FSU Jena, 2002.

[7] a) Weber, B; Kaps, E.; Weigand, J.; Carbonera, C.; Letard, J. F.; Achterhold, K.; Parak, F.-G.; Inorg. Chem. 2008, 47, 487-496; b) Weber, B.; Kaps, E. S.; Obel, J.; Bauer, W.; Z. Anorg. Allg. Chem. 2008, 1421-1426; c) Weber, B.; Carbonera, C.; Desplanches, C.; Létard, J.-F.; Eur. J. Inorg. Chem. 2008, 1589-1598; d) Weber, B.; Kaps, E. S.; Desplanches, C.; Létard, J.-F.; Achterhold, K.; Parak, F. G.; Eur. J. Inorg. Chem. 2008, 4891-4898; e) Bauer, W.; Weber, B.; Inorg. Chim. Acta 2009, 362, 2341-2346. f) Weber, B.; Kaps, E.; Heteroatom Chem. 2005, 16, 391-397; g) Weber, B.; Walker, F.-A.; Inorg. Chem. 2007, 46, 6794-6803; h) Weber, B.; Kaps, E. S.; Obel, J.; Achterhold, K.; Parak, F. G.; Inorg. Chem. 2008, 47, 10779-10787. i) Weber, B.; Tandon, R.; Himsl, D.; Z. Anorg. Allg. Chem. 2007, 633, 1159-1162; j) Weber, B.; Kaps, E. S.; Desplanches, C.; Létard, J.-F.; Eur. J. Inorg. Chem. 2008, 2963-2966.

[8] team of authors in Organikum, Wiley-VCH, Weinheim, 2004, vol. 22 , p. 753.

[9] L. Wolf, E.-G. Jäger, Z. Anorg. Allg. Chem. 1966, 346, 7691.

[10] E.-G. Jäger, E. Häussler, M. Rudolph, M. Rost, Z. Anorg. Allg. Chem. 1985, 525, 67-85.

[11] E. Díez-Barra, A. de la Hoz, A. Sánchez-Migallón, J. Tejeda, Hetreocycles 1992, 34, 1365-1373.

[12] L. D. Field, B. A. Messerle, M. Rehr, L. P. Soler, T. W. Hambley, Organometallics 2003, 22, 2387-2395.

[13] A. Altomare, M. C. Burla, G. M. Camalli, G. Cascarano, C. Giacovazzo, A. Guagliardi, A. G. G. Moliterni, G. Polidori, R. Spagna, "SIR 97", Campus Universitario Bari, 1997; J. Appl. Crystallogr. 1999, 32, 115.

[14] G. M. Sheldrick, "SHELXL 97", University of Göttingen, Germany, 1993.

[15] C. K. Johnson, M. N. Burnett, "ORTEP-III", Oak-Ridge National Laboratory, Oak-Ridge 1996; Farrugia, L. J.; J. Appl. Cryst. 1997, 30, 565.

Received: ((will be filled in by the editorial staff)) Published online: ((will be filled in by the editorial staff) 


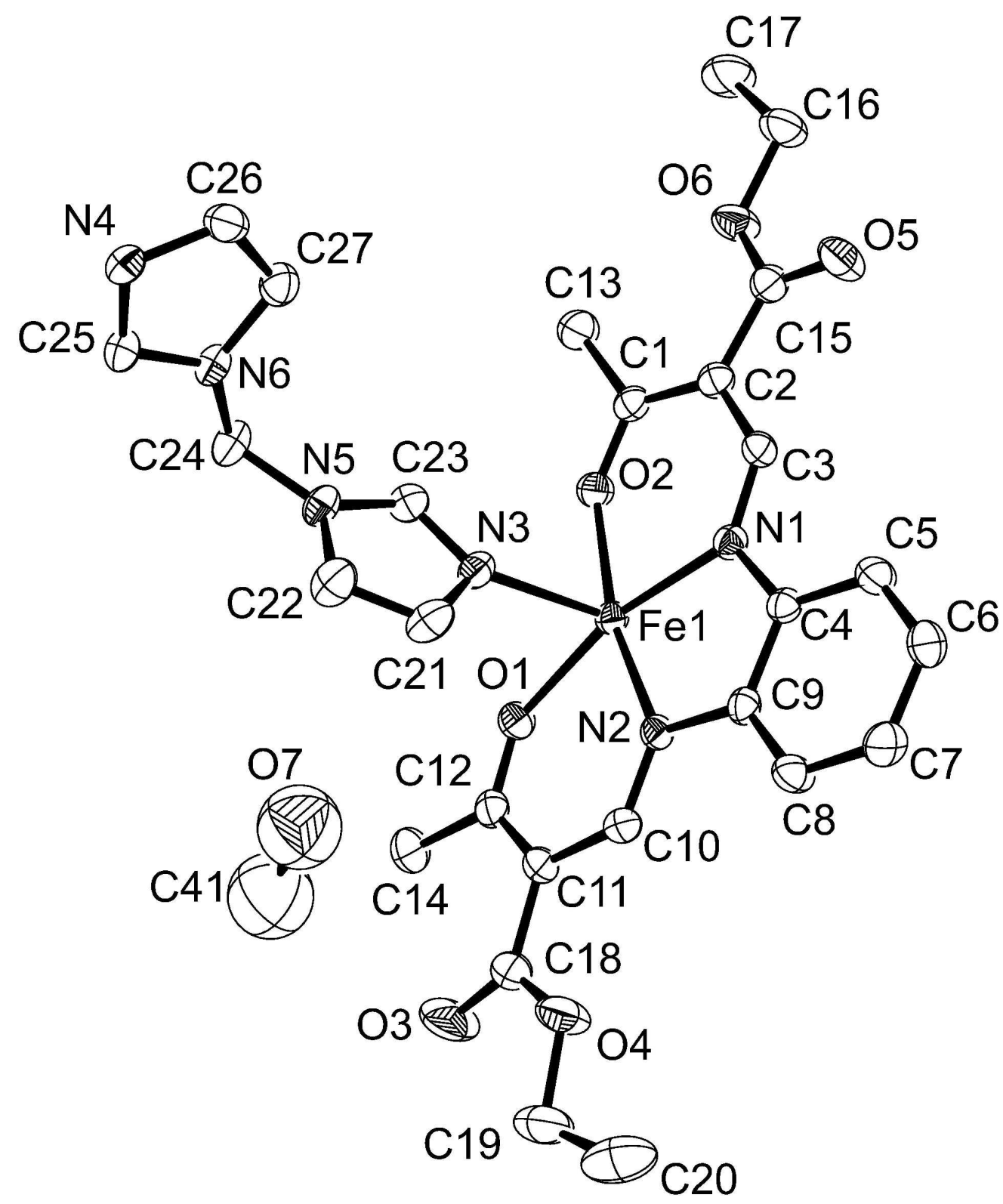

ORTEP drawing of the asymmetric unit of 1 . Hydrogen atoms were omitted for clarity. Thermal ellipsoids are shown at the $50 \%$ probability level. $162 \times 195 \mathrm{~mm}(600 \times 600 \mathrm{DPI})$ 

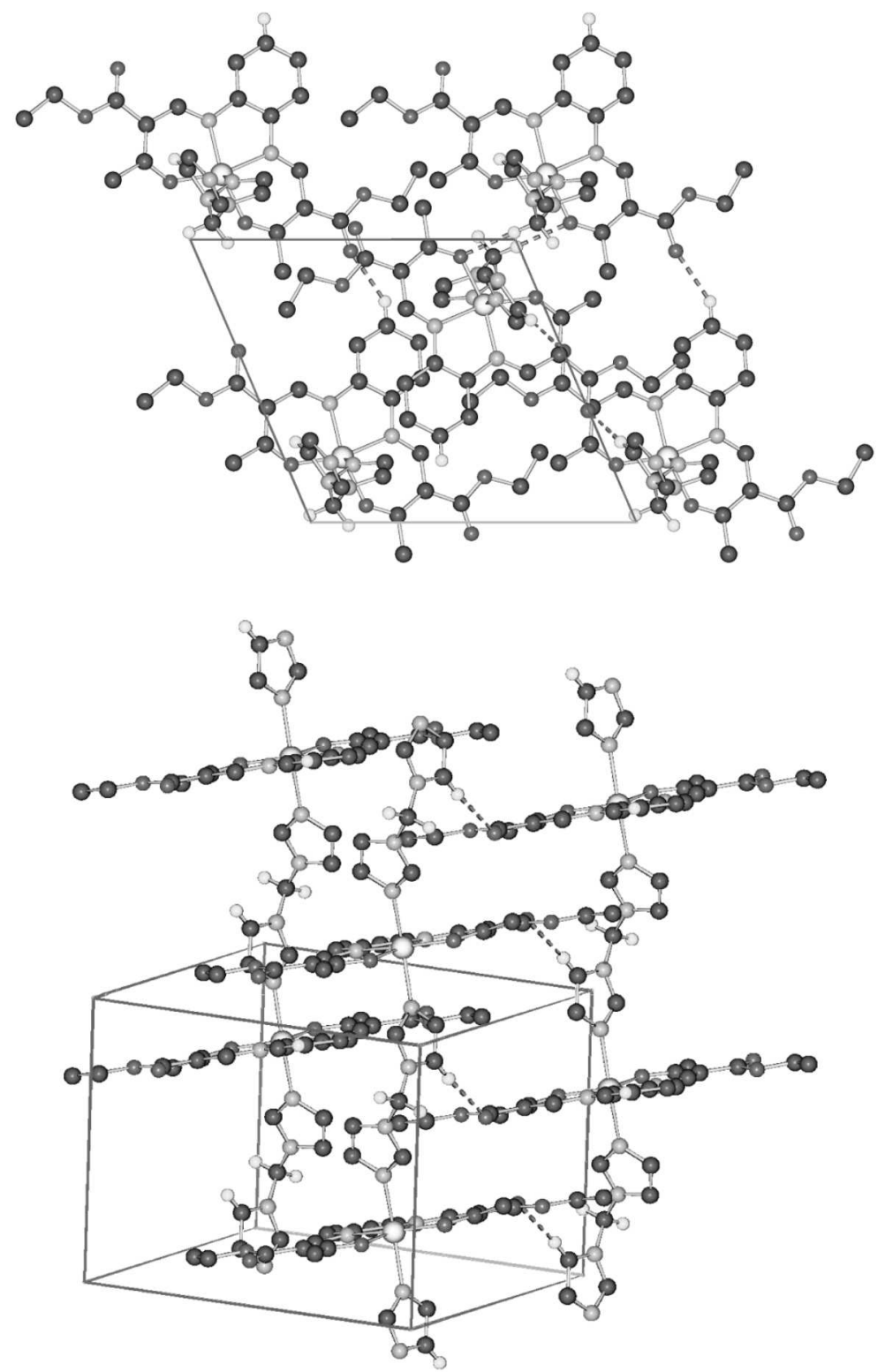

Top: Packing of compound 1 in the crystal at $200 \mathrm{~K}$; view along [100], bottom: excerpt of a 2D layer of parallel polymer chains. Solvent molecules and $\mathrm{H}$-atoms, which do not participate in $\mathrm{H}$ bonding, have been omitted for clarity. $99 \times 159 \mathrm{~mm}(300 \times 300 \mathrm{DPI})$ 

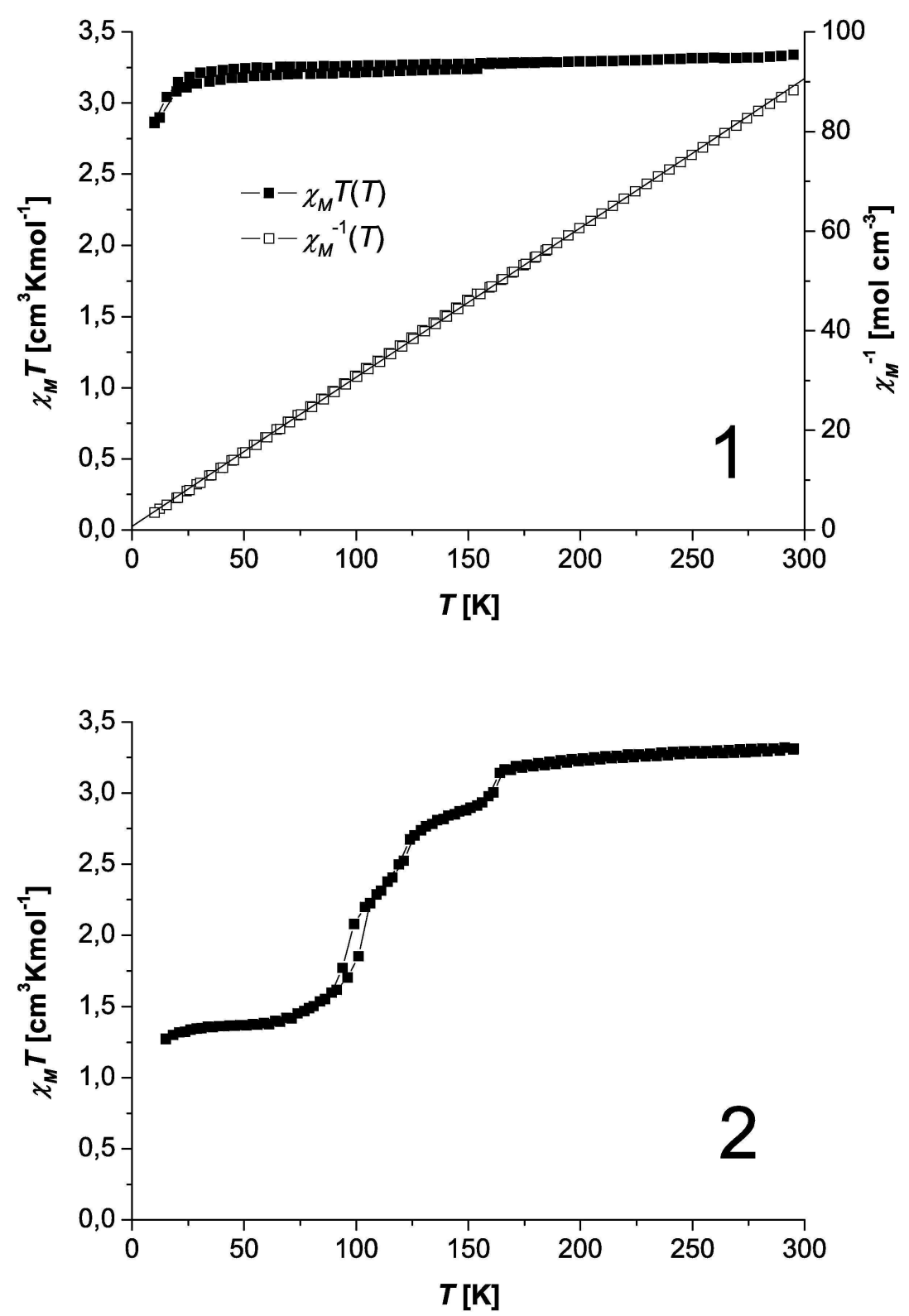

Plots of XMT product (filled squares) vs. T for the compunds 1 and 2. Reciprocal molar susceptibility $X \mathrm{X}-1$ (open squares) as function of temperature $T$ and the fits according to the Curie Weiss law, $X \mathrm{M}$ $=\mathrm{C} /(\mathrm{T}-\Theta)$, with the parameters $\Theta=-2.71 \mathrm{~K}, \mathrm{C}=3.34 \mathrm{~cm} 3 \mathrm{Kmol}-1$ for compound 1 . $102 \times 150 \mathrm{~mm}(600 \times 600 \mathrm{DPI})$ 
<smiles>[R]C1CN2c3ccccc3N3CC([R])N4CC(C)=C(C)O[C@]24O[P+](OC)(C=C1C)O3</smiles>

$\left[\mathrm{FeL}(\mathrm{MeOH})_{2}\right]$

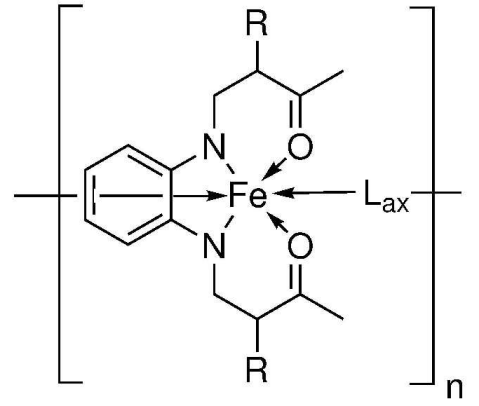

[FeL(bimm)]

L1: $R$ = COOEt

L2: $\mathrm{R}=\mathrm{COMe}$

General procedure for the synthesis of the 1D octahedral iron(II) coordination polymers. $157 \times 70 \mathrm{~mm}(600 \times 600 \mathrm{DPI})$ 